\title{
Who Is Who in the Teaching of Sex Education? A Lesson Learned from the 'Safuu' Oromo Tradition of East Africa
}

\author{
Admasu Etefa Tucho ${ }^{1}$ \\ ${ }^{1}$ Associate Professor of Education, Lincoln University of Pennsylvania, USA \\ Correspondence: Admasu Etefa Tucho, Associate Professor of Education, Lincoln University of Pennsylvania, \\ USA.
}

Received: November 15, 2021

Accepted: December 29, 2021

Online Published: January 6, 2022

doi:10.5539/jel.v11n2p49

URL: https://doi.org/10.5539/jel.v11n2p49

\begin{abstract}
The 2020 National Center for Education Statistics (NCES) data show that there are a total of 130,930 k-12 public schools in the United States of America (U.S.A), serving approximately 48.1 million students. The demographic breakdown of the student population includes 22 million (45.7\%) Whites; 13. Million (32\%) Hispanic; 17.2 million (14\%) African American; 2.6 million (5.4\%) Asian, 2.2 million (4.6\%) students two or more races; and 0.4 million (0.8\%) American Indian/ Alaska Native students. Adding sex education to the public school curriculum was primarily to make elementary and secondary school students aware of sexually transmitted diseases and teenage pregnancy. Although comprehensive sexuality education has been operational in all 50 states for decades, the program's quality and comprehensiveness vary considerably from state to state due to a series of obstacles. The author of this article proposes an alternative or at least supplemental approach to the current comprehensive sex education.
\end{abstract}

Keywords: Safuu, Gada, Oromo, public school, sex education

\section{Background}

This article examined the relationship between sex education, often known as Comprehensive Sexuality education, offered in American public schools and immigrant communities' challenges in the United States. Comprehensive sexuality education (C.S.E.) is a curriculum-based process of teaching and learning about the cognitive, emotional, physical, and social aspects of sexuality (UNESCO, 2017). It teaches issues relating to human sexuality, including human sexual anatomy, sexual activity, sexual reproduction, age of consent, safe sex, and birth control (Ibid). Today, sex education has become a global issue where confrontations between supporters and opponents have become a constant reality. Although most school districts seek parents' consent for their children to participate in sexuality education programs, many parents still firmly believe that the lesson goes against their family traditions and want to block it for good (Mayer, 1997). Notably, most immigrant families do not feel comfortable even hearing, let alone talking, about subjects related to human sexuality and the reproductive system in public or around persons younger than their ages, including their children, who view it as a taboo subject. They believe that it is the responsibility of parents to handle such sensitive matters as sex education and sexual orientation. They also insist that any study subjects offered in schools where their children attend must honor families' traditional values and heritage as practiced by ancestors for generations. As a result, a large majority of the immigrant communities prefer to leave the matter exclusively to the child's parents alone. Although the sex education curriculum offered in American public school classrooms focuses mainly on preventing sexually transmitted diseases and unwanted teen pregnancy, many immigrant communities still perceive it as an unwarranted act against their cultural heritage and family values. Finally, the inclusion of sexual orientation lessons in the existing sex education curriculum caused further panic among immigrant communities who believe children's exposition to the gay and lesbian lifestyle would likely influence or urge them to experiment with it (Kauchak \& Eggen, 2011). Therefore, whose responsibility is to teach sex education to students enrolled in U.S. public schools? What is the minimum age for students who take sex education classes? May tradition-oriented child-rearing from a young age to adulthood commonly practiced by religious communities and traditional value bonds like the "Safuu" Oromo tradition be an alternative to controversial sex education programs in the U.S. public schools? 


\section{History of Sex Education in the U.S. Public Schools}

The history of sex education in the U.S. has roots in the National Education Association (N.E.A.). Alarmed by mass migration from rural to urban cities, in 1892, the N.E.A. first discussed the urgency of adding sex education to public school curriculum at its 34th annual conference in Saratoga Spring, New York, where it passed a resolution that called for "moral education in the schools" (Bigelow et al., 1916). In 1912, the N.E.A. once again affirmed its position on sex education as a valuable tool to help school children prepare for life in the subject matter. Then, with the start of WWI in 1914, the American Social Hygiene Association (ASHA) provided lifesaving lessons to American soldiers on the importance of sex education and sexually transmitted diseases before their departure to the war front (Cornblatt, 2009). Indeed, in the 1920s, many public secondary schools became more inspired by the military's sex education programs and began integrating sex education into their curriculums. The aim was to equip middle and high school students with basic knowledge about the spread of sexually transmitted diseases like syphilis and gonorrhea and prevent unwanted teen pregnancies (Ibid.).

There were several hurdles and challenges sex-related education in public schools faced and still facing in the United States. Such oppositions are mainly from churches, conservatives, and parents who believed that sex education in public schools encouraged promiscuity, moral corruption and exposed their children to homosexuality (Jensen, 2007). Opponents argued that sex education should be left to parents who know better about their children and family values. At the same time, supporters acknowledged the importance of having broad cooperation from home, church, and community organizations for the resolution's success (ASHA, 1938).

\section{Who Is Who in the Child's Sex Education?}

Indeed, sex education teachers always expect parents to do their part by providing the necessary advice to keep their child away from having unprotected sexual intercourse, thereby preventing consequences that follow. Atienzo and Walker (2009) urged parents to get involved in their child's sex education because it can impact their child's future sexual health. Ashcraft and Murray (2017) also stressed the need for parents, guardians, and other caregivers to get involved in providing a fundamental and critical lesson to adolescents about sexual education before it is too late. Despite the need for parental involvement, for most parents and their children, the prospect of talking about topics related to sexuality creates anxiety and apprehension, which may lead to avoidance of discussions.

In many tradition-oriented immigrant communities where family values and customs have major impacts on marriages or relationships, the issue of permitting schools to teach their children about sex or human sexuality is a complicated matter to handle. Indeed, talking about sex in such societies is a very irritating subject. For example, a study on parents in Nigeria, West Africa, showed that mothers were unwilling to talk about sex or sex education to their daughters. The same is true for Indian mothers who felt embarrassed talking about taboo subjects like sex with their daughters (Sharma, 2005). Instead, these culturally interwoven communities prefer someone younger or in the girls' age group and trusted by parents to deliver essential information about male-female relationships and the necessary care to be taken before marriage.

In the meantime, these immigrant communities also realize that they are no longer in their home country, where they used to practice their traditional values and cultural heritages freely. They must adjust to the new reality without totally dropping their moral and ethical values. These parents also know that they have a great responsibility in helping their adolescent children adjust to behavioral and value changes they face in schools and neighborhoods, which are likely at odds with the ones they experience at home.

As human beings, people often commit irreversible errors like having children out of wedlock repeatedly, sometimes from different fathers, and become remorseful later for their past bad judgments. A study shows that adolescents with half-siblings from multiple fathers are more likely to have used drugs and had sex by age 15 than those with only full siblings (Guzzo \& Dorius, 2013). This finding reminds us of the old saying of "You reap what you sow," which means you eventually have to face up to the consequences of your actions. There is also a proverb commonly used among Oromo people of East Africa that sounds like "Gaabbi fi Eegeen Booddee Deemti," which means, Regret and tail always follow from behind. Therefore, it would be difficult for parents as an individual or couples who led careless and immoral lifestyles in the past who lacked ethical values and the quality of responsible parenthood to behave later as role models for their children. This is also true for parents who carelessly use vulgar language or profanities while children are around, or those who have sexual intercourse while school-age children are watching lack moral credibility to tell children not to do what they frequently do themselves (Kenea, 2015). Therefore, the question remains whether the issue of sex education should be left to classroom teachers alone or to look for alternative approaches available out there to deal with this taboo subject. 


\section{The Debate}

Study shows that well-designed and culturally sensitive sex education programs keep family values honored and stay strong (Zimmerman, 2015). Unfortunately, the efforts to advance sex education in public schools using media networks and other means of communication became controversial among many sections of society, especially when the curriculum involves LGBTQ topics. Many view sex education as anti-moral values. Hurn (1985) noted a formidable resistance to comprehensive sex education from several conservative and religious groups. The religious groups think the very discussion of human sexuality in schools goes against religious and moral values. They argue that their children should not be exposed to something as taboo as sex in their school, and such teachings go against their religious beliefs. Most of those who oppose sex education in public schools advocate for the teaching of 'abstinence-only' supplemented by character education and moral values (Ibid).

Sex Education in American public schools has broad support from public and health organizations, including the American Medical Association, the American Academy of Pediatrics, and the Society for Adolescent Health and Medicine. According to Planned Parenthood's report (February 9, 2017), more than 93\% of parents supported sex education in middle and secondary schools. More than $90 \%$ of them felt that parents and public health professionals should determine sexuality education content and opposed the involvement of politicians.

Although most parents and school systems support the teaching of sex education in public schools, only 13 states in the nation require sex education to be medically accurate. Many school districts also allow parents to consent or reject that their children participate in sex education classes, including discussions involving sexual orientation and birth control (Gollnick \& Chinn, 2013). Sex education opponents further strengthened their opposition base by adding character and moral education to the sex education curriculum. This group believed that the decline in traditional family structure and the erosion of moral values contributed to young people's involvement in sexual experimentation. As a result, the opposition camp prioritized the teaching of character education and moral values over just sex and sexual orientation where the idea later gained strong support from parents, school employees, and the community for the development and implementation of moral and character development in public education (Kauchak \& Eggen, 2011).

\section{Safuu: A Term with High Value}

Although some sexually explicit words or phrases have been heard in streets and several households around the world as uttered by a few reckless individuals, generally speaking; however, sex is a taboo word in most traditional societies and social settings. Taboos are social norms that have a massive effect on people's daily activities. In many traditional communities, the way people behave, dress, eat, and communicate are all governed by norms and taboos. For example, for the Oromo people of East Africa, uttering words associated with sex or sexual expression in public or at home in the presence of children of any age is considered immoral and unethical as governed by an unshakable moral value called $\boldsymbol{S a f u u}$ (Kenea, 2015). Safuu is an indigenous moral system made up of ethical principles involving concepts such as right and wrong and the expression of duties and obligations. It is one of the highly enforced and respected rules of law in the Gada System (Legesse, 1973). Gada is a traditional system of governance used by the Oromo people in Ethiopia and Northern Kenya and is believed to be the oldest democratic system existing long before the introduction of Western democracy in which the power transition occurred from one democratically elected leadership team to another every eight years (Ibid). The system, among others, enforces moral conduct, builds social cohesion, and promotes the importance of Oromo traditional values and heritages. Bartels (1986) reported that the Safuu concept has a strong religious dimension. According to this report, in relationships between family members and other members of society, Safuu implies paying respects to and keeping a distance. It stands out in ritual sayings like: "small and big are $\boldsymbol{S a f u u}$ to one another; old and young are Safuu to one another; daughter and mother are $\boldsymbol{S a f u u}$ to one another; son and father are $\boldsymbol{S a f u u}$ to one another, and daughter and son are $\boldsymbol{S a f u u}$ to one another." In every Oromo speech,

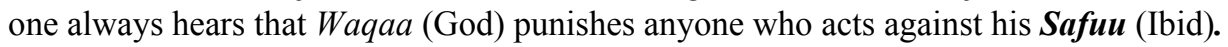

Like many other immigrant communities in North America, the Oromo families also try to raise their children following the guideline of the Safuu tradition. Accordingly, Oromo children are urged to respect one another, avoid cursing or using vulgar language anytime, and respect older persons, including their parents, close or distant family members, and all human beings (Kenea, 2015). In Oromo culture, the responsibilities of preparing young girls for post-puberty age by inculcating very basic values of life skills in the minds of these youngsters lie on the shoulders of mothers, girls of the same age groups in the neighborhood, or "Addoyyee," and recently married female members of the community. As for boys, male family members, including fathers, uncles, relatives, and other boys of the same age groups in the community, or "Qeerroo," play a vital role in guiding them into the fullness of their masculinity or manhood. 
To sum up, the purpose of sex education is to help adolescents and teenagers enrolled in public schools protect themselves from sexually transmitted diseases, avoid teen pregnancy, have a cordial relationship with one another, and be good role models for younger ones. Likewise, the teaching of Safuu Oromo tradition also teaches the importance of having a cordial and socially acceptable relationship with one another guided by moral values.

In conclusion, regardless of the parents' ethnic or socio-economic backgrounds, the child's education begins at home. Parents must use commonsense to coach a child in the right direction. A child needs someone trustworthy in and outside the house. Parents must supplement the comprehensive sex education lesson provided to the child in the classroom with their family values and moral principles to help the child become a reliable and productive member of society. Realistically, not all parents are indeed responsible parents. For those parents who lack ethical and moral values, schools and community leaders must get involved to help them learn how to become responsible parents. They must learn how to behave well with children and avoid using vulgar language anywhere around the house.

\section{References}

American Social Hygiene Association (1938). Hygiene, Sexual, Social problems, Sex instruction, Hygiene, Sex Education. Journal of Social Hygiene. Retrieved on April 18, 2021, from https://archive.org/details/journalofsocialh24amerrich

Ashcraft, A. M., \& Murray, P. (2017). Talking to Parents About Adolescent Sexuality. P.M.C. Journal, 64(2), 305-320. https://doi.org/10.1016/j.pcl.2016.11.002

Atienzo, E., \& Dilysm, W. (2009). Parent-adolescent Communication about Sex in Morelos, Mexico: Does it Impact Sexual Behavior? The European Journal of Contraception \& Reproductive Health Care, 14(2), 111-119. https://doi.org/10.1080/13625180802691848

Bartels, L. (1986). Some More Notes About the Oromo Concept of Ayyaana and the Use of the Word in Everyday Speech. A Paper Submitted to the 9th International Conference of Ethiopian Studies in Moscow, August 1986. Unpublished Article.

Bigelow, M. A., Balliet, T. M., \& Morrow, P. A. (1916). The Matter and Methods of Sex. New York: American Federation for Sex Hygiene. Retrieved November 12, 2021, from https://www.worldcat.org/title/report-of-the-special-committee-on-the-matter-and-methods-of-sex-educatio n-presented-before-the-subsection-on-sex-hygiene-and-demography-held-in-Washington-dc-september-twe nty-third-to-twenty-eighth-nineteen-hundred-and-twelve/oclc/27953652

Cornblatt, J. (October 27, 2009). A Brief History of Sex Ed in America. Newsweek. Retrieved September 5, 2019, from https://www.newsweek.com/brief-history-sex-ed-america-81001

Darroch, J. E., Singh, S., \& Frost, J. J. (2001). Differences in Teenage Pregnancy Rates Among Five Developed Countries: The Roles of Sexual Activity and Contraceptive Use. Family Planning Perspective, 33(6), 244-250. https://doi.org/10.2307/3030191

Feeney, S., Nolte, S., \& Christensen, D. (2010). Who Am I in the Lives of Children? An Introduction to Early Childhood Education (8th ed.). Pearson Education, Inc., Boston, MA.

Furstenberg, F. M., \& Peterson, J. (1985). Sex Education and Sexual Experience Among Adolescents. American Journal of Public Health (AJPH), 75(11), 1331-1332. https://doi.org/10.2105/AJPH.75.11.1331

Gollnick, D., \& Phillip, C. (2013). Multicultural Education in a Pluralistic Society (9th ed.). Pearson Education, Inc.

Guzzo, K., \& Dorius, C. (2013). Negative Effects of Half-Siblings. American Sociological Association (A.S.A.). Retrieved October 5, 2019, from http://www.sciencedaily.com/releases/2013/08/130811005336.htm

Hurn, C. (1985). The Limits and Possibilities of Schooling: An Introduction to the Sociology of Education (2nd ed.). Allyn \& Bacon, Inc.

Jeannine, C., \& Guy, S. P. (1983). Sociocultural Determinants of Parental Involvement in Sex Education. Journal of Sex Education and Therapy, 9(2), 22-25. https://doi.org/10.1080/01614576.1983.11074777

Jensen, R. E. (2007). Using Science to Argue for Sexual Education in U.S. Public Schools: Dr. Ella Flagg Young and the 1913 "Chicago Experiment". Science Communication, 29(2), 217-241. https://doi.org/10.1177/1075547007309101

Kauchak, D., \& Eggen, P. (2011). Introduction to Teaching: Becoming a Professional (4th ed.). Pearson Education, Inc. Merrill Prentice Hall. 
Kenea, D. A. (2015). Safuu: The Indigenous Oromo Moral System. Addis Ababa, Ethiopia.

Lafferty, M. (2008). Abstinence-only and Comprehensive Sex education and the Initiation of Sexual Activity and Teen Pregnancy. The Center for the Advancement of Health, 42(4), 344-351. https://doi.org/10.1016/j.jadohealth.2007.08.026

Legesse, A. (1973). Oromo Democracy: An Indigenous African Political System. Asmara, The Red Sea, Inc.

Marques, M., \& Ressa, N. (2013). The Sexuality Education Initiative: A Program Involving Teenagers, Schools, Parents, and Sexual Health Services in Los Angeles, CA, U.S.A. Reproductive Health Matters, 21(41), 124-135. https://doi.org/10.1016/S0968-8080(13)41702-0

Mayer, R. (1997). Trends in Opposition to Comprehensive Sexuality Education in Public Schools in the United States, 1996-1997. Sexuality Information and Education Council Across the United States (SIECUS) Report, 25(6), 20-26.

National Center for Education Statistics (NCEA, 2020). Back-to-School. Retrieved August 22, 2021 from https://nces.ed.gov/fastfacts/display.asp?id=372\#K12-enrollment

People for the American Way. (2019). The Religious Right and School Boards: The 1992-93 School Year. Executive Summary. Retrieved July 15, 2019, from https://www.aclu.org/other/campaigns-undermine-sexuality-education-public-schools\#4

PlannedParenthood. (February 9, 2017). Retrieved September 3, 2019, from https://www.plannedparenthood.org/learn/for-educators/whats-state-sex-education-us

Sharma, N. (2005). Parents' Attitude Towards Imparting Sex Education to Their Adolescent Girls. Anthropologist, 7(3), 97-199. https://doi.org/10.1080/09720073.2005.11890907

The National Conference of State Legislatures (NCSL). (October 2019). State Policies on Sex Education in Schools: Why Is Sexual Education Taught in Schools? Retrieved November 2, 2019, from $\mathrm{http}: / / \mathrm{www} . \mathrm{ncsl}$.org/press-room/ncsl-in-the-news-october-2019.aspx

UNESCO. (2017). International Technical Guidance on Sexuality Education (pp. 16-17). UNESCO Health and Education Resource Centre. Retrieved December 10, 2020, from https://csetoolkit.unesco.org/toolkit/getting-started/what-comprehensive-sexuality-education

USAID Health Policy Initiative. (2003). Archived from the original (PDF) on November 8, 2013.

Zimmerman, J. (March 16, 2015). The World's Problem with Sex Education. New York Times. Retrieved November 10, 2019, from https://www.nytimes.com/2015/03/16/opinion/culture-religion-andsex-education.html

\section{Copyrights}

The author retains the copyright for this article, with first publication rights granted to the journal.

This is an open-access article distributed under the terms and conditions of the Creative Commons Attribution license (http://creativecommons.org/licenses/by/4.0/). 